\title{
伊予灘および豊後水道付近の地震活動
}

\author{
日本エヌ・ュー・エス株式会社 片山幾夫*・安中 正* \\ (昭和 56 年 5 月 26 日受理)
}

\section{Seismic Activity in and around the Iyonada and Bungo Channel}

\author{
Ikuo KATAYAMA and Tadashi ANNAKA \\ Japan NUS Co., LTD. \\ (Received May 26, 1981)
}

Seismicity in the Iyonada and Bungo channel area is discussed with emphasis on the feature of focal distribution in recent earthquakes, including the microearthquakes detected by the Ikata microearthquake observation network during the period from Nov. 1975 to Jan. 1980.

The principal conclusions obtained for this region are:

(1) Seismicity in the uppermost mantle is very high, while that in the crust is remarkably low.

(2) Earthquakes in the uppermost mantle have their foci concentrated within a thin layer of almost $10 \mathrm{~km}$ thickness. This active layer descends in low angle towards northwest direction at the depths of 30 to $50 \mathrm{~km}$, and then becomes steep in its slope to westerly direction as the depth exceeds $50 \mathrm{~km}$. These observations suggest that these earthquakes occurred in the near surface of descending Philippine Sea Plate.

(3) There seems to exist a northern boundary in the seimic area of the uppermost mantle.

(4) Infrequent microearthquakes (magnitude less than 2.0) detected in the upper crust seem to have an apparent linear distribution parallel to the trend of Sada-Misaki Peninsula.

(5) The magnitude-frequency relationship for the uppermost mantle earthquakes was in good agreement with those in both the recent earthquakes determined by Japan Meteorological Agency since 1961 and that reported major disastrous earthquakes in this region since the late 16 th century. This fact suggests that those disastrous earthquakes in historic times could be better designated to seismic activity in the uppermost mantle descending beneath the crust, than to the activity in "Median Tectonic Line".

\section{§1.はじめに}

1975 年の末以来, 愛媛県佐田岬半島の伊方町で四国電力 (株)により 3 点観測網の高感度微 小地震観測が行なわれており，貴重なデータが得られている．我々はそれらのデータを解析す る機会を得た. 本稿では 1975 年 11 月から 1980 年 1 月までの 4 年 3 ケ月間のデータを解析した 結果に基づき，伊予灘拈よび豊後水道付近の地震活動——特に震源分布一一特徴を報告する. 
伊予灘叔よび豊後水道付近の地震活動は,「フィリピン海 プレート」の沈み込みとの関連 [Shiono and Mikumo(1975); 溝上 (1976); SHIONo (1977)など] で, また中央構造線の現 在の活動性との関連 [SHIONO (1974，1980)；松田 (1975)；SHIMAZAKI（1976)など] で検討 されて和り，地震学的に注目されている。そして SHIONO (1977) によれば，この地域は西南 日本外帯下の最上部マントルの地震活動と九州拉よび琉球列島下の最上部マントルの地震活動 の境界に相当し, 震源分布と発震機構の性質が急激に変化する地域と考えられて挍り，その点 からもこの地域の地震活動の特徴の解明が求められている.

しかし, この地域は大学を中心とする高感度微小地震観測網の範囲からややはずれており，

SHIONO and MASAOKA (1978) を除いては，微小地震までをも含めた地震活動の検討はほと んど行なわれていない. SHIONO and MASAOKA（1978）は，この地域の中心近くに臨時観測 点を設置し，気象庁および周辺の高感度微小地震観測点のデータとあわせて震源を決定してお り，気象庁により決定された震源に比べ深さの精度を改善している，その結果は本稿の結果と 調和的であるが，震源決定された地震は約 90 個程度であるため震源分布の詳しい特徴までは 明確になつていない。

従つて, 本稿での解析結果は伊予灘および豊後水道付近の地震活動の検討にとつて基礎的な

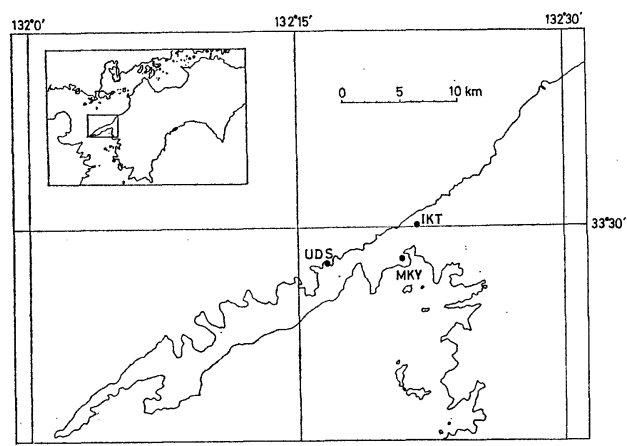

Fig. 1. Location of Ikata microearthquake observation network; UDS-Udonose, MKY-Mukaiyama and IKT-Ikatagoshi stations.
データを提供しうるものと考える。

\section{§2. データおよび解析}

四国電力(株)により行なわれている 3 点観測網 (伊方観測網) の配置を Fig. 1 飞, その座標を Table 1 に示す．各 観測点の座標は空中写真を用いた航空 三角測量により決定されたものである. 各観測点には速度型地震計 3 成分が 設置され，トリガー方式抒よび低速連

Table 1. Geographical co-ordinate of each station.

\begin{tabular}{|c|c|c|c|}
\hline Station & $\begin{array}{l}\text { Geog } \\
\text { Latitude }\end{array}$ & $\begin{array}{l}\text { linate } \\
\text { Longitude }\end{array}$ & Altitude $(\mathrm{m})$ \\
\hline UDS; Udonose & $33^{\circ} 28^{\prime} 22^{\prime \prime} \mathrm{N}$ & $132^{\circ} 16^{\prime} 28^{\prime \prime} \mathrm{E}$ & 79.45 \\
\hline MKY; Mukaiyama & $33^{\circ} 28^{\prime} 35^{\prime \prime} \mathrm{N}$ & $132^{\circ} 20^{\prime} 45^{\prime \prime} \mathrm{E}$ & 203.25 \\
\hline IKT; Ikatagoshi & $33^{\circ} 30^{\prime} 07^{\prime \prime} \mathrm{N}$ & $132^{\circ} 21^{\prime} 35^{\prime \prime} \mathrm{E}$ & 256.68 \\
\hline
\end{tabular}


続方式による 2 種類の記録がデータレ コーダに採録されている. 1977 年 1 月末以後の観測システムの概要を Fig. 2 に示す。 それ以前の観測システムと の違いは刻時装置にあり，1977 年 1 月末に JJY 受信機が増設され，JJY 信号のパルスが時計信号のパルスに重 ね合わされるよらになり，1 日 1 回 NHK FM 放送の時報により行なつて いる自動較正の状態が正確に把握でき るようになつた。な拈， 3 点の設備が 完成し記録が取れ始めたのは 1975 年 9 月末であるが, 解析可能なデータが 得られているのは 1975 年 11 月中旬 以後である.また， 1976 年の 4 月頃 までは記録の $\mathrm{S} / \mathrm{N}$ 比や時計の自動較 正を改善するために関連部分の機器が 変更されて和り，観測条件が注淁安定 するようになるのは 1976 年の 5 月以 後である。

トリガー方式による記録は四国電力 （株）により約 $40 \mathrm{~mm} / \mathrm{sec} の$ 紙送りで 再生されている記録を用いた。再生さ れた記録例を Fig. 3 亿示す。低速連 続方式による記録はカセットテープの 形で提供されたものから， Fig. 4 に

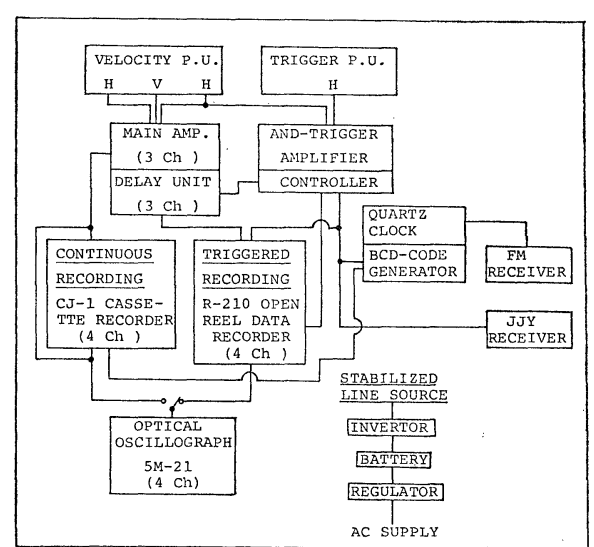

Fig. 2. Schematic diagram of the observation system at each station.
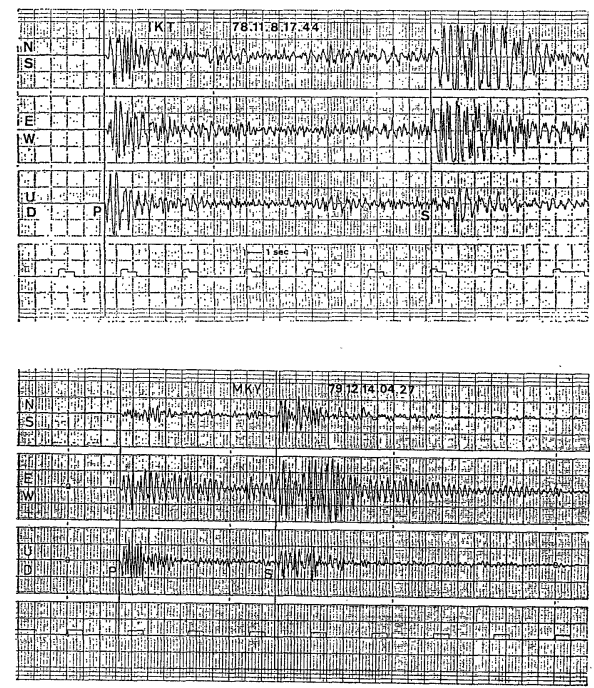

Fig. 3. A representative triggered record form of microearthquakes displayed from R-210 Data Recorder on a chart of pen oscillograph and used for source determination.

示した方法で，地震を検出し再生した記録を用いた．再生された記録例を Fig. 5 に示す．低 速連続方式による記録の再生は 1 点について行ない, 基本として MKY の記録を用い, MKY の記録がない場合は IKT, UDS の順で代替した.

観測網の辺長が短いため震源を精度良く決定するには $\mathrm{P}$ 波と $\mathrm{S}$ 波の到着時刻の読み取りに かなりの精度が必要になる. その点を考虑して, 震源決定の対象は 3 点で同時にトリガー方式 


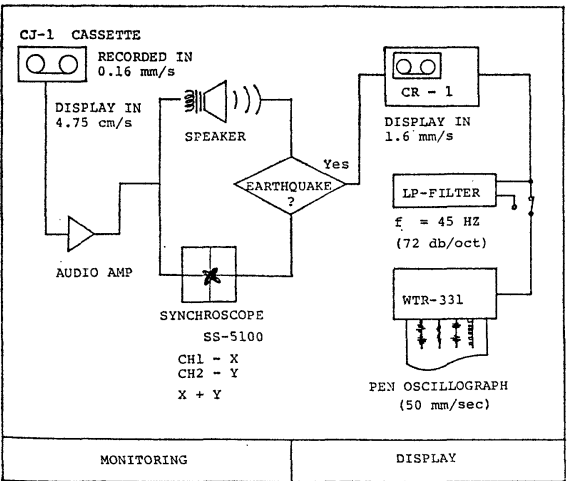

Fig. 4. Flow chart of identifying and displaying microearthquakes recorded on CJ-1 Continuous Cassette Recorder.

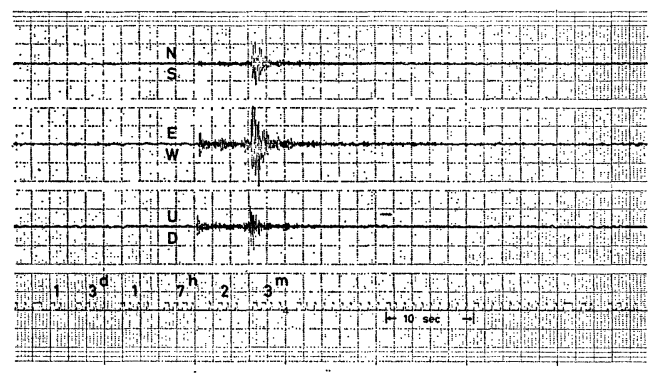

Fig. 5. A representative record form of a microearthquake detected on CJ-1 Continuous cassette Recorder of MKY and displayed on a chart of pen oscillograph and used as supplemental data for evaluating statistically the seimicity of the region.
による記録が得られている地震で，観 測網での S-P 時間が 20 秒程度までの 地震とした。それらの地震に関しては， 再生記録から $\mathrm{P}$ 波と $\mathrm{S}$ 波の到着時刻, $\mathrm{P}$ 波の初動方向, また可能な場合には 地震動継続時間（F-P 時間）を読み取 つた。そして，震源決定の対象とした 地震も含めて，観測網により検知され たすべての地震に対して，P 波の到着 時刻，S-P 時間，F-P 時間を読み取つ た．それらの読み取りはトリガー方式 の記録がある地震はそれを用いて，ま た無い地震は低速連続方式による記録 を用いて行なつた。また，明らかに採 石発破によると判断できた記録につい ては以下の解析結果から除外した.

震源決定は尾池（1975） と同じ方法 を用いて行なつた。すなわち，発震時 $\left(t_{0}\right)$ を $\mathrm{P}$ 波到着時刻 $\left(t_{p}\right)$ と $\mathrm{S}-\mathrm{P}$ 時間 $\left(t_{s-p}\right)$ から, $t_{0}=t_{p}-t_{s-p} /\left(V_{p} / V_{s}-1\right)$ の式を用いて決定した上で， 3 点の $\mathrm{P}$ 波 走時 $\left(t_{p}-t_{0}\right)$ を用いて震源を決定した. $\mathrm{P}$ 波の速度構造は，青木・村松 (1974) 等でこの地域 の周辺に推定されている速度構造や，観測網の中で行なわれた発破の観測結果を考慮して作成 した Fig. 6 の構造を用い, $V_{p} / V_{s}$ は 1.73 と仮定した.

マグニチュードは Fig. 7 に示した式 $(M=2.92 \mathrm{log}(\mathrm{F}-\mathrm{P})$-2.66) を用いて決定した。 こ の式は，マグニチュードと $\log$ (F-P) が比例する [津村 (1967)] と仮定して求めたものであ り, 1976 年 4 月までのデータについては前述したようにそれ以後のものと同一の基準では扱 えないと考觉られるので除いて，1976 年 5 月から 1978 年 11 月までのデータを用いた.

\section{§3. 地震活動の概要}

震源分布の詳しい特徵は次節以降で検討することにし，ここでは観測網により検知された地 
震に関する結果を中心に解析結果の概 要を示し, あわせてこの地域の地震活 動の概要を示す。この節での検討は MKY の S-P 時間を基準に行ならた めに，震源分布の細かな特徴を検討す ることは出来ないが，ある程度以上の 大きさの地震はすべて検知していると 考えられるので, 地震活動の水準を検 討することは可能である.なお，前述 したように MKY の記録がない場合 には他の観測点で代替しているが，観 測網が小さいために S-P 時間の差は 小さく, ここでの検討の範囲内ではそ の影響は問題にならないと考兄られる.

検知された地震拉よび震源決定され た地震に対する S-P 時間別頻度分布 を Fig. 8 に示す. 2 つの分布の傾向 は一致して拈り，S-P 時間で 4.6 秒 を境として頻度分布に鋭いコントラス トが存在する点が特徴的である。この ような鋭いコントラストは，後述する ように, この地域の地震の大部分が厚 さ $10 \mathrm{~km}$ 程度の薄い層内で発生して おり，その層の中心が観測網付近で約 $45 \mathrm{~km}$ の深さにあるために，そしてそ の層より浅い領域の地震活動が非常に 低いために生じたものである (Fig. 17 (b) 参照).

Fig. 9 は S-P 時間が 9 秒未満の地

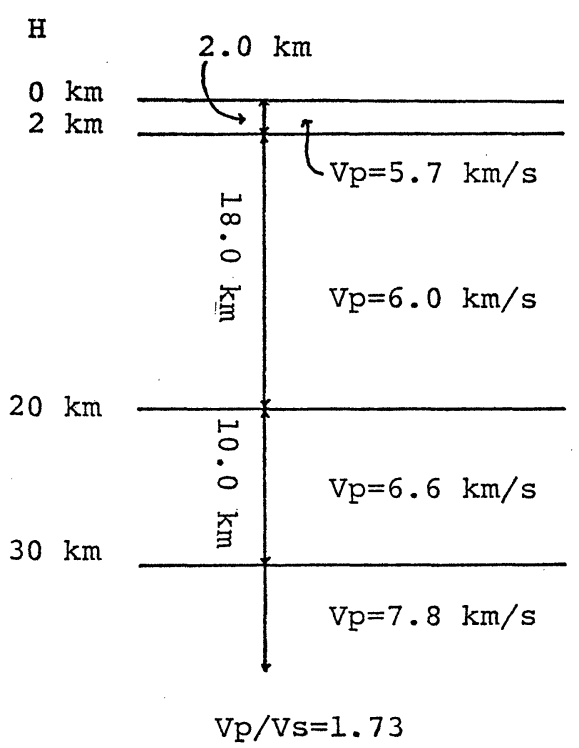

Fig. 6. The semi-infinite multi-layered underground model used for source determination.

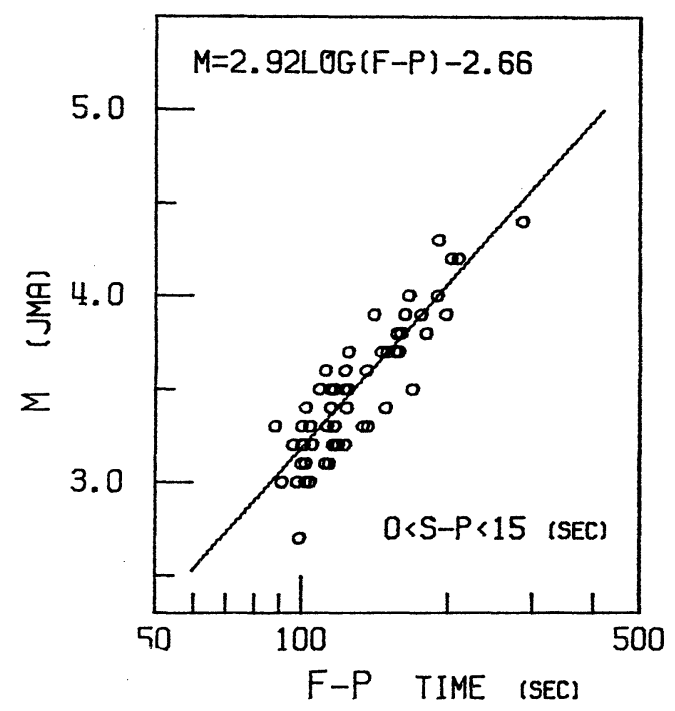

Fig. 7. Relation between the total durations of oscillation (F-P) at MKY station and the magnitudes determined by the Japan Meteorological Agency (J. M. A.).

震に対してマグニチュード $(M)$ と頻度の関係を示したものであり， $M \gtrsim 1.5$ の地震がほぼも れなく検知され， $M \gtrsim 2.0$ の地震の震源が注ぼもれなく決定されていることを示している. 

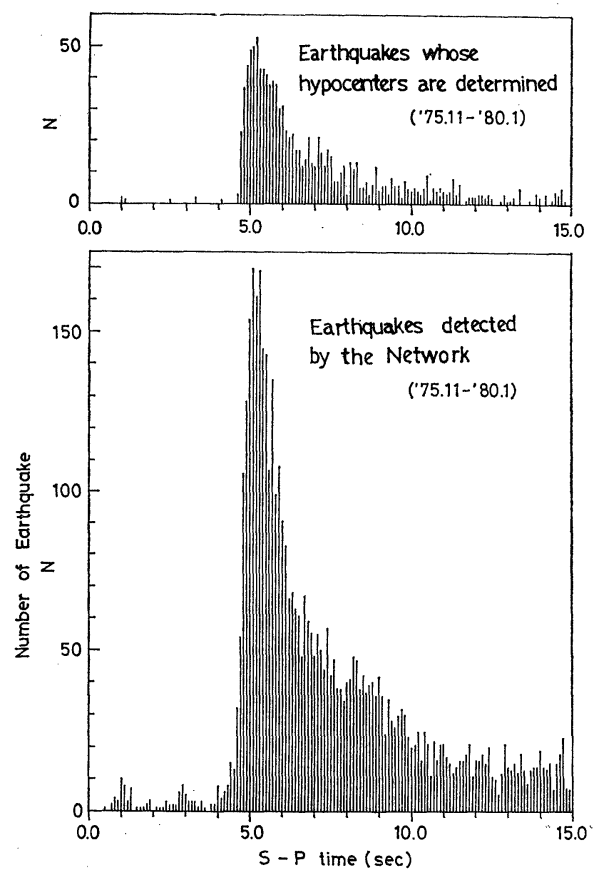

Fig. 8. Distribution of the number of earthquakes detected by the network classified in S-P time intervals at MKY. The upper distribution is for those earthquakes whose hypocenters are determined.
検知された地震に関して,$M \geqq 2.0$ の 範囲で最尤法により $b$ 值を 決定する [宇津 (1965)] と, $b=0.81$ となる. また，トリガー方式による観測が 3 点 とも正常に行なわれ, 震源決定が可能 であつた期間がどの程度であつたかを 単純に $M \geqq 2.5$ の地震数で推定する と, 検知された地震が 506 個, 震源決 定された地震が 296 個であり約 58\% の期間になる。測の主たる原因は， トリガーレベルを越えるノイズが頻発 することによるテープの巻き終わりと 機器の故障である.

検知された地震に関する月別地震数 の変化を Fig. 10 に示す. 初期の 6 ケ月間を除くと, S-P 時間が 9 秒未満 の地震数は注ぼ一定水準にあり, 特に 顕著な活動の変化はみられない，初期
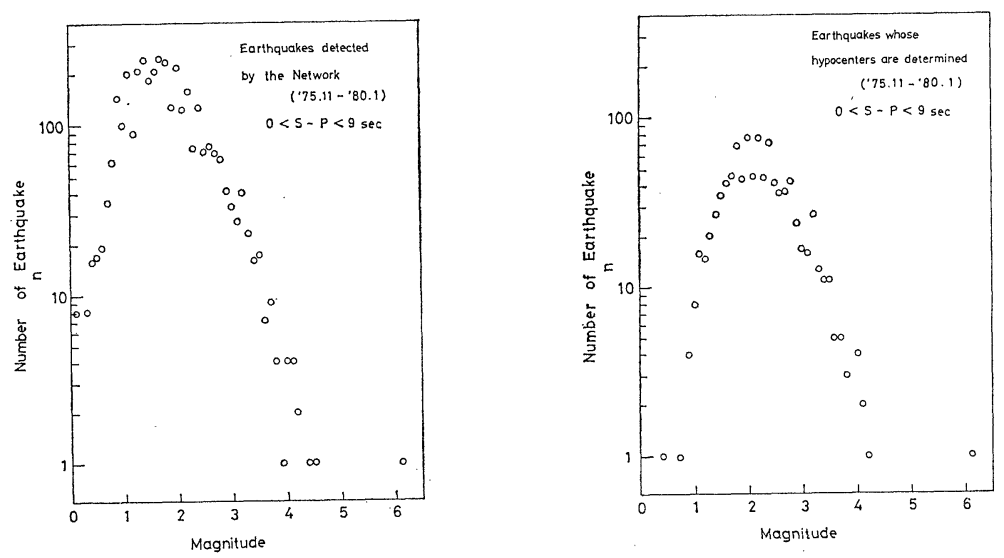

Fig. 9. Mangnitude-frequency relationships for the earthquakes detected by the network (left), and for those earthquakes whose hypocenters are determined (right). 

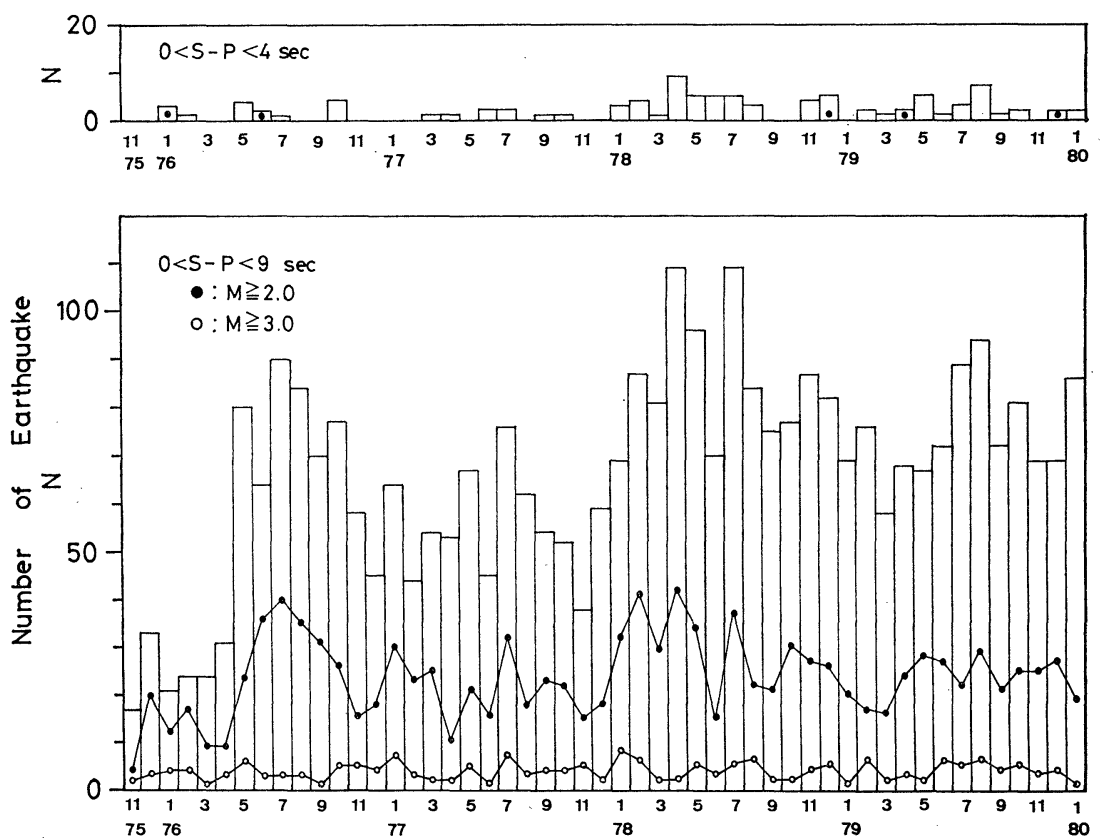

Fig. 10. Monthly distribution of earthquakes detected by the network; the upper shows those earthquakes extracted from the lower in condition of S-P time less than 4 seconds.

の 6 ケ月間で地震数が少ないのはその時期の検知能力が低かつたためと考えられる。また， S-P 時間が 4 秒未満の範囲では，地震数が非常に少ないとともに $M \geqq 3.0$ の地震がまつたく 発生していない点が特徵的である.

次に, 今回解析した 4 年 3 ケ月間の地震活動の水準が, 気象庁により観測されている最近約 19 年間の地震活動の水準や過去の被害地震の記録が示す最近約 400 年間の地震活動の水準と どのような関係にあるかを Fig. 11 に示す. 白丸 $(O)$ は伊方観測網により検知された S-P 時 間が 9 秒未満の地震に関して, 黒丸 $(○)$ は同じ S-P 時間の範囲にほぼ見合う範囲 $\left(131^{\circ} 40^{\prime} \mathrm{E}\right.$ $\sim 133^{\circ} 00^{\prime} \mathrm{E}, 32^{\circ} 50^{\prime} \mathrm{N} \sim 34^{\circ} 10^{\prime} \mathrm{N}$, 深さ $\left.0 \mathrm{~km} \sim 70 \mathrm{~km}\right)$ に気象庁により 震源決定された地震 (1961 年 1 月から 1980 年 1 月までの期間) に関して, そして三角 $(\triangle)$ は同じ範囲に震央が ある 16 世紀末以後に発生した被害地震に関して, マグニチュードと累積頻度の関係を示した ものである．ただし，被害地震の震源パラメータは 1884 年以前の地震は宇佐美 (1975), 1885 年から 1925 年までの地震は宇津 (1979), そして 1926 年以後の地震は気象庁が決定したもの を用いた. Fig. 11 には参考として $\log N=4.6-1.0 M$ の線を示したが，全体的にみて 3 つ のデータ群の示す地震活動の水準は非常に良く調和していると考えられる. 


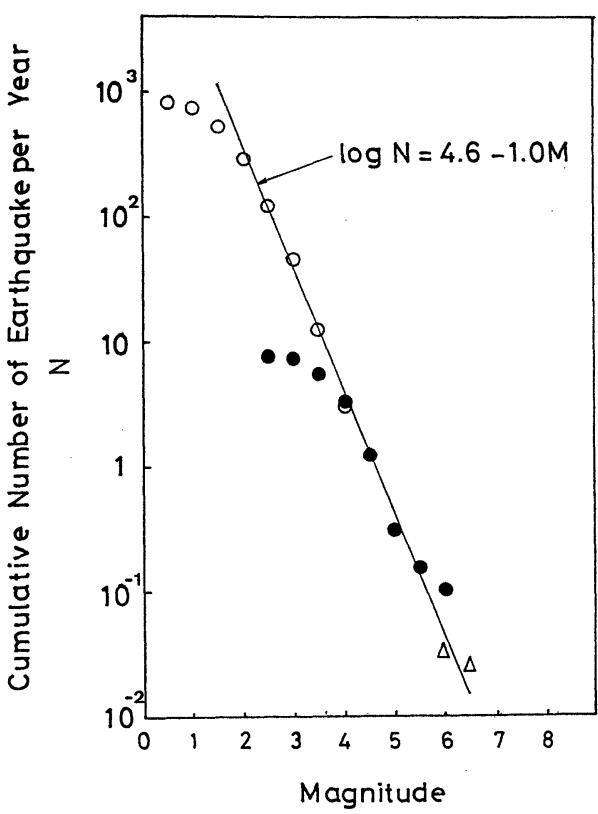

Fig. 11. Relation between magnitude and cumulative number of earthquakes per year by using earthquake data detected by the Ikata network during 11/18/75 through $1 / 31 / 80$ (open circles), those by J.M. A. during $1 / 1 / 61$ through $1 / 31 / 80$ (solid circles) and the major disastrous earthquakes since the late 16 th century (open triangles) for the region within 9 seconds by S-P time at MKY station.

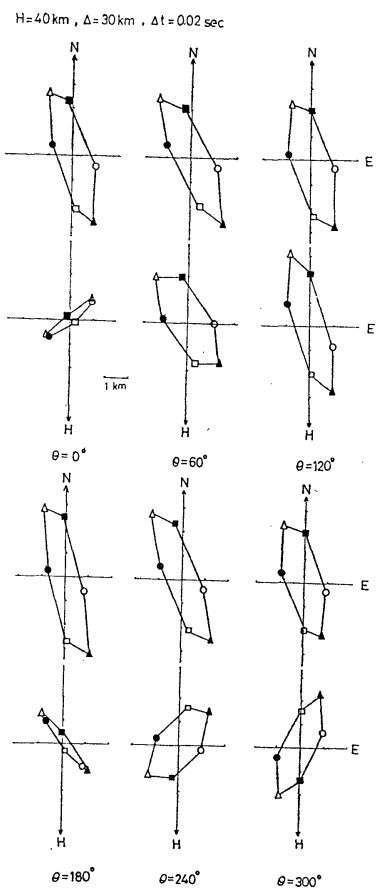

Fig. 12. Examples of hypocentral deviation by assumed reading error $\pm \Delta t$ of $\mathrm{H} P$ arrival time at UDS (circles), MKY (triangles) and IKT (squares). Open and solid symbols represent $+\Delta t$ and $-\Delta t$ respectively. Hypocenter is defined by epicentral distance $(\Delta)$ from the center of gravity of the triangle formed by the Ikata network, by azimuth $(\theta)$ which is measured in degree anti-clockwise from east and by depth $(H)$.

\section{§4. 震源決定精度について}

震源分布の特徵を検討する準備として，この節では伊方観測網の震源決定能力や精度に関し て 2 つの面から検討を行なら．1つは，理論走時の周りにずらせた走時を用いて決定した震源 が，最初仮定した震源からどの程度移動するかを検討するものであり，読み取り精度と震源決 定精度の関係を見積もることが出来る.もう1つは, 気象庁の観測点配置が本地域の地震を取 り囲む形であるために震央に関しては比較的信頼できると考兄られるので，伊方観測網により 決定された震源を気象庁により決定された震源と比較することにより，観測網近傍の異常な速 度構造などを原因とする震源決定の系統的な偏りが存在するかどうかを調べるものである. 

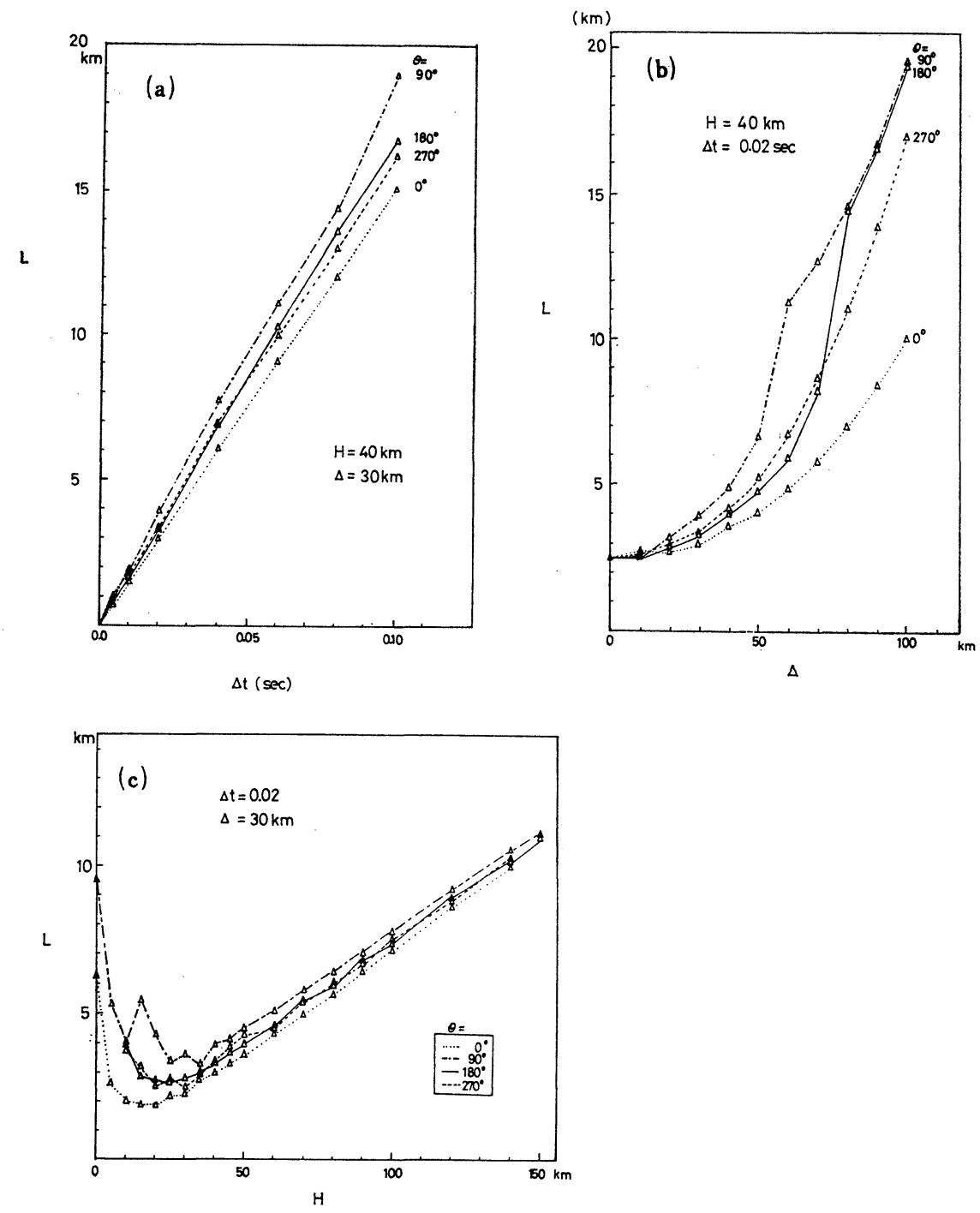

Fig. 13. Plots of the magnitude of hypocentral deviation $(L)$ by reading error $\Delta t$ of $\mathrm{P}$ arrival time at MKY; (a) in case of varying $\Delta t$, (b) in case of varying $\Delta$ and (c) in case of varying $H$.

\section{i）震源移動の大きさ}

Fig. 12 和よび Fig. 13 に検討結果を示す. Fig. 12 には，最初に仮定した震源（観測網 の作る 3 角形の外心を中心として, 東方向を $0^{\circ}$ として反時計回りに測つた方位 $\theta$, 震央距離 $\Delta$ と深さ $\mathrm{H}$ により定義される) を中心にして, $\mathrm{P}$ 波の理論走時から各観測点の走時を $\pm \Delta t$ だけずらせた 6 通り（UDSをずらせた時は円 $(O), \mathrm{MKY}$ の時は三角 $(\Delta), \operatorname{IKT}$ の時は四角 


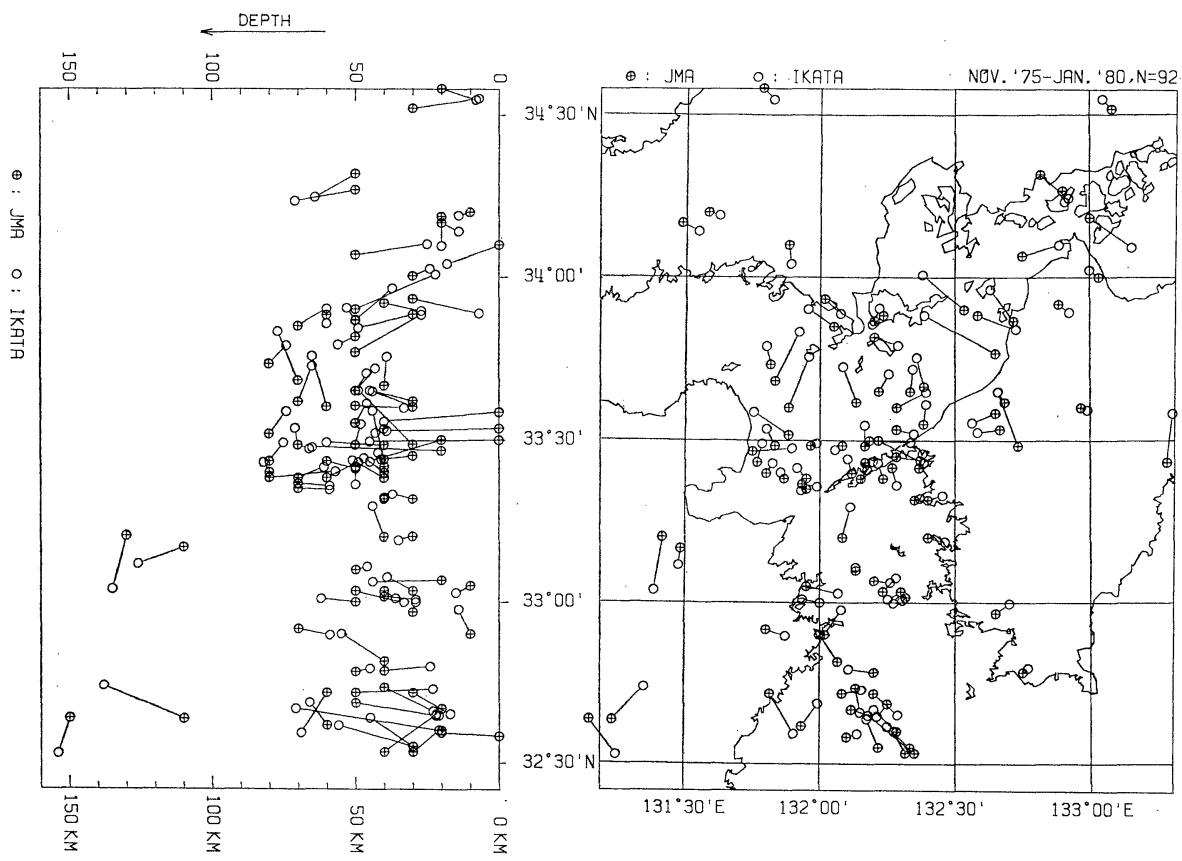

Fig. 14. Specific comparison of hypocenters determined by the Ikata microearthquake network with those by J.M.A..

（口）で示し，白ぬきと黒ぬりでそれぞれ+ $\Delta t$ およびー $\Delta t$ ずらせた時を示す）について，そ の走時を用いて決定した震源の動きを示した。この場合は観測網に震源が比較的近い例である. まず，震央の動きをみると，MKY と IKT をずらせた時の南北方向への動きが相対的に大き く，東西方向への動きに比べ約 $2 \sim 3$ 倍である，次に，深さ方向への動きをみると， $\theta=120^{\circ}$ ， $300^{\circ}$ の方向で MKY と IKTをずらせた時の動きが相対的に大きい。これらの傾向は最長辺 (UDS-IKT) の走向が $\theta \approx 22^{\circ}$ であり，その辺と MKY との距離がかなり短いという観測網 の形状によるものである.

Fig. 13 には各パラメータに対する震源移動の大きさ $(L)$ の変化を示した. Fig. 13 は MKY の走時をずらせた時の結果であるが，Fig. 12の例で示されているように，UDS とIKT の走 時をずらせた時の震源移動の大きさは MKY の場合に比べ一般に小さい. Fig. 13 (a) は $\Delta t$ の増加に対し $L$ がほぼ直線的に増加していくことを示している. そして， $\Delta t=0.02$ 秒とした 時の $\Delta$ と $H$ に対する $L$ の変化がそれぞれ Fig.13 (b) と Fig.13 (c) に示されている. 本稿 の解析で $\mathrm{P}$ 相の立ち上がりが明確な地震に対しては，その読み取り誤差が $1 / 100$ 秒以内と考 えられ，観測点間の誤差が累積した場合でも観測点間の相対的な誤差は $2 / 100$ 秒以内と考㝋ら 


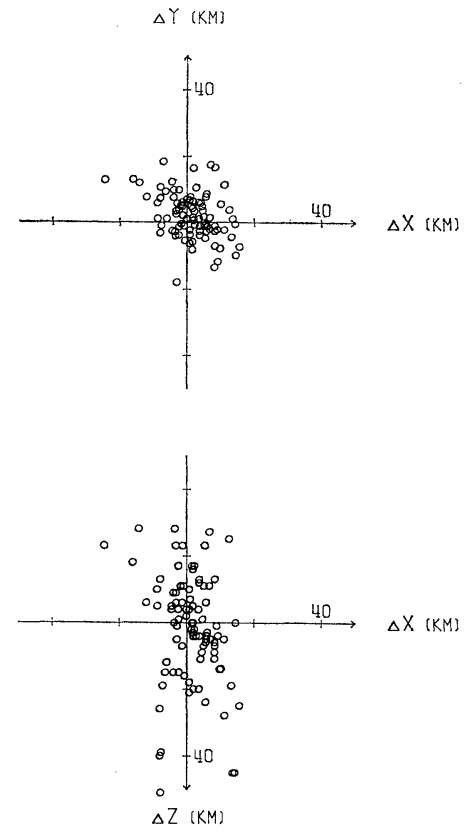

Fig. 15. Comparison of location of earthquakes determined by the Ikata microearthquake network with thosed etermined by J. M. A. during $11 / 18 / 75$ through $1 / 31 / 80$; the upper and the lower denote horizontal and vertical deviations respectively.

れる所から Fig. 13(b) (c) では $\Delta t=$ 0.02 秒と設定した. Fig. $13(\mathrm{~b})$ は深 さ $40 \mathrm{~km}$ の最上部マントルの地震の 場合, $\Delta$ が $50 \mathrm{~km}$ 以内の範囲では $L$ がほぼ $5 \mathrm{~km}$ 以下になること、ムが $50 \mathrm{~km}$ より大きくなると $L$ はかなり 急激に大きくなることを示している. また，Fig. 13 (c) は比較的観測網に 近い $\Delta=30 \mathrm{~km}$ の場合でも深さ $10 \mathrm{~km}$ 以下の地殼内の地震に対しては $L$ が かなり大きくなりることを示してい る.

以上の検討には発震時の誤差の影響 は含まれていない。発震時の誤差は $\mathrm{S}$ 波の到着時刻の決定誤差に依存するが， $\mathrm{S}$ 波の判定に波形上 1 周期程度の誤差 があると考劣るとその大きさは本稿で 解析した波形では $1 / 20$ 秒程度である.

発震時の誤差はその約 1.4 倍であり，その大きさは $1 / 10$ 秒以下である. 本稿の場合, 観測網 が小さいために発震時の誤差の影響は主に観測網から震源までの距離に現われ，その方には あまり関係しないと考光られる。距離への影響は $V_{p}=7.8 \mathrm{~km} / \mathrm{sec}$ とすると $1 \mathrm{~km}$ 以下であ る.

以上述べた所から，伊方観測網で決定された震源に関して，本稿で主に検討する観測網から 半径 $50 \mathrm{~km}$ 程度以内の最上部マントルの地震の場合, 読み取りの精度が良い地震の震源の決 定誤差は震源の移動量にして $5 \mathrm{~km}$ 程度以下であると考えられる.

\section{ii）気象庁により決定された震源との比較}

Fig. 14 および Fig. 15 に検討結果を示す. Fig. 14 は各地震毎に比較したものであり, Fig. 15 は気象庁により決定された震源を中心として伊方観測網により決定された震源の相対 的な分布を示したものである．Fig．15 の上側の困から，気象庁による震央を中心とするほぼ 半径 $10 \mathrm{~km}$ の円の中に伊方観測網による震央の大部分が分布していることがわかる. 北西一 南東方向への偏りが北東一南西方向に比べて若干大きい傾向があるのは前述した観測網の形状 


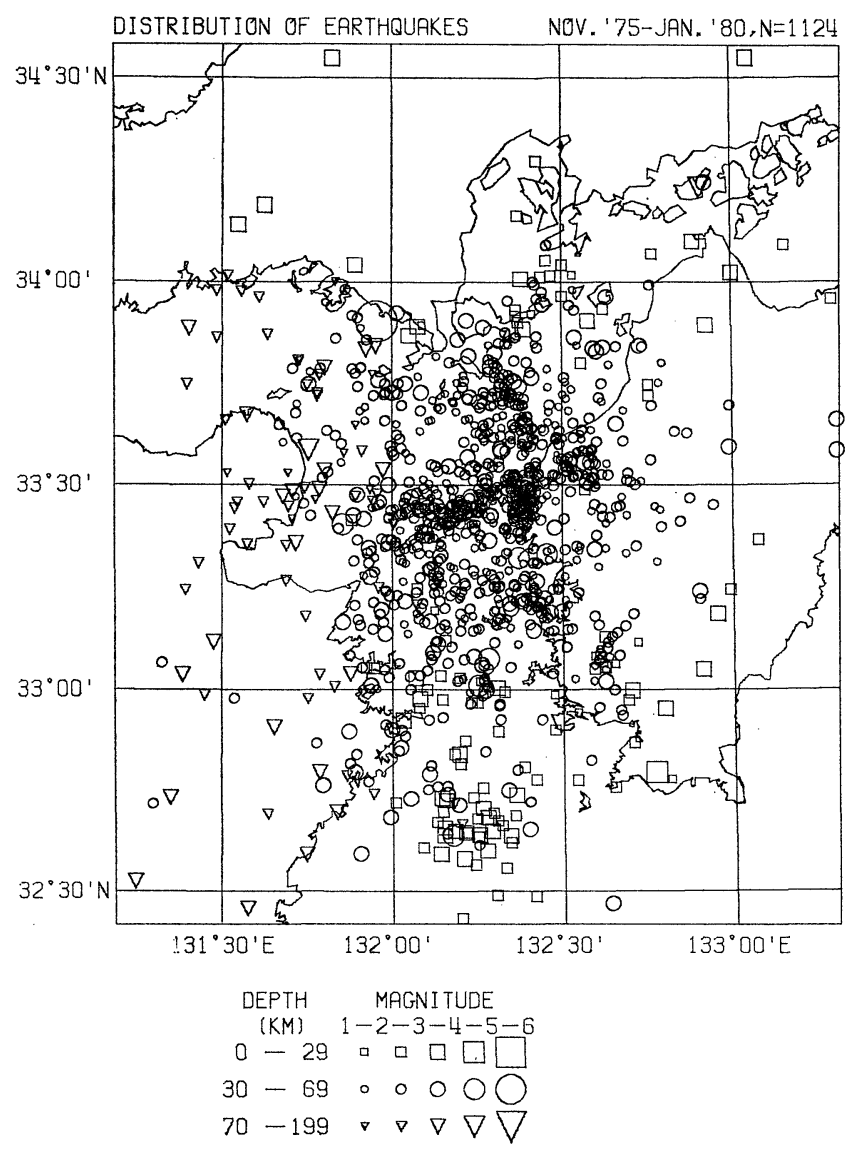

Fig. 16. Epicentral distribution of earthquakes whose hypocenters are determined by the Ikata microearthquake network during 11/18/75 through 1/31/80.

の影響が現われていると思われるが，全体としてこの程度に両者の震央が合致することは伊方 観測網による震源決定に特に問題となるような系統的な偏りが存在しないことを示すものと考 学らる。

震源の深さに関しては分布の範囲が震央に比べ大きいが， $\pm 20 \mathrm{~km}$ をとれば大部分がその中 に分布している (Fig. 15 の下側の図)，乙かし，両者による震源の深さにかなりの差がある 地震もある. Fig. 14 の断面図で伊方観測網に比較的近い $33^{\circ} 30^{\prime} \mathrm{N}$ 付近に, 気象庁により深 さが $0 \mathrm{~km}$ ないし $20 \mathrm{~km}$ に決定されている 5 個の地震があるが，それらは伊方観測網ではい ずれも $39 \mathrm{~km}$ 以上の深さに決定されている，それらの地震について各観測点の走時偏差を調 べたが，気象庁による震源では伊方観測網の各点での走時偏差の絶対值がかなり大きくなるの に対し，伊方観測網による震源では気象庁の各点の走時偏差の絶対值が十分小さくなつた。こ のことから考えて，それらの地震の震源の深さは伊方観測網によるものの方が妥当であり，そ 
れらが地殼内の地震でないのは確実である.

\section{§5. 震源分布の特徵}

今回解析した 1975 年 11 月から 1980 年 1 月までの地震の震源分布を Fig. 16 に示す. Fig. 16 には図に示した範囲に震央が決定された地震を深さにより記号を変えてプロットした. 大部分の地震が深さ $30 \sim 69 \mathrm{~km}$ の最上部マントルに発生した地震であること，分布に偏りが あり非常に密に分布する領域（佐田岬半島沿いやその付根を通り南北にのびる領域など）と， 地震があまり発生していない領域（佐田岬半島の南側の宇和海やその北側の伊予灘など）が存 在することが特徴的である.

次に，震源分布の特徴をより詳しく調べるために Fig. 17 (a) に示した各範囲に対して作成 した断面図を Fig. 17 (b) に示す. Fig. 17 (b) では P 波の立ち上がりが 3 点とも十分明確 な地震 $(\bigcirc)$ とやや不確かなものを含む地震 $(+)$ を区別した，東西断面図では，東から西へ震源 が深くなる傾向が顕著であり，大部分の地震が厚さ $10 \mathrm{~km}$ 程度の層内に分布している．観測 網からやや難れたＡの範囲では，震源がやや分散して分布しているように見兄るが，精度が 良いと考えられる地震 $(○)$ だけに注目するとかなり系統的に東から西へ深くなる傾向が見られ る. 南北断面図では, 此較的浅い範囲 (E や F) で南から北に向けてやや深くなつていく傾向 が見られる。また, 最上部マントルの 地震が発生する北限が比較的明瞭に存 在するようである $(\mathrm{F}, \mathrm{G}, \mathrm{H})$. 今回 震源決定した地震の中で最も大きな 1979 年 7 月 13 日の地震 $\left(M_{J}=6.1\right)$ はその北限近くで発生した $(\mathrm{H})$. なお， この 7 月 13 日の地震は余震が非常に 少ないのが特徵的であり, 余震と考光 られるものは約 4 分後に発生した 1 個 の地震だけであつた。

最上部マントルの地震の分布の特徴 をまとめたものとして, 震源の深さの 等深線とその発生する北限の推定位置 を Fig. 18 に示す. Fig. 18 の等深 線で示されている面を中心とする深さ

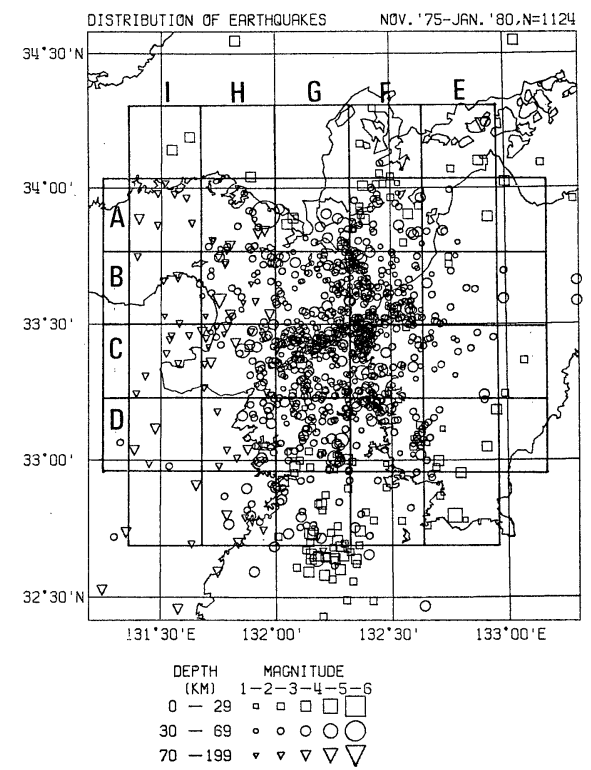

Fig. 17 (a). Allocation of sectional divisions from A through I for detailed discussion on the focal distribution features of the region concerned. 

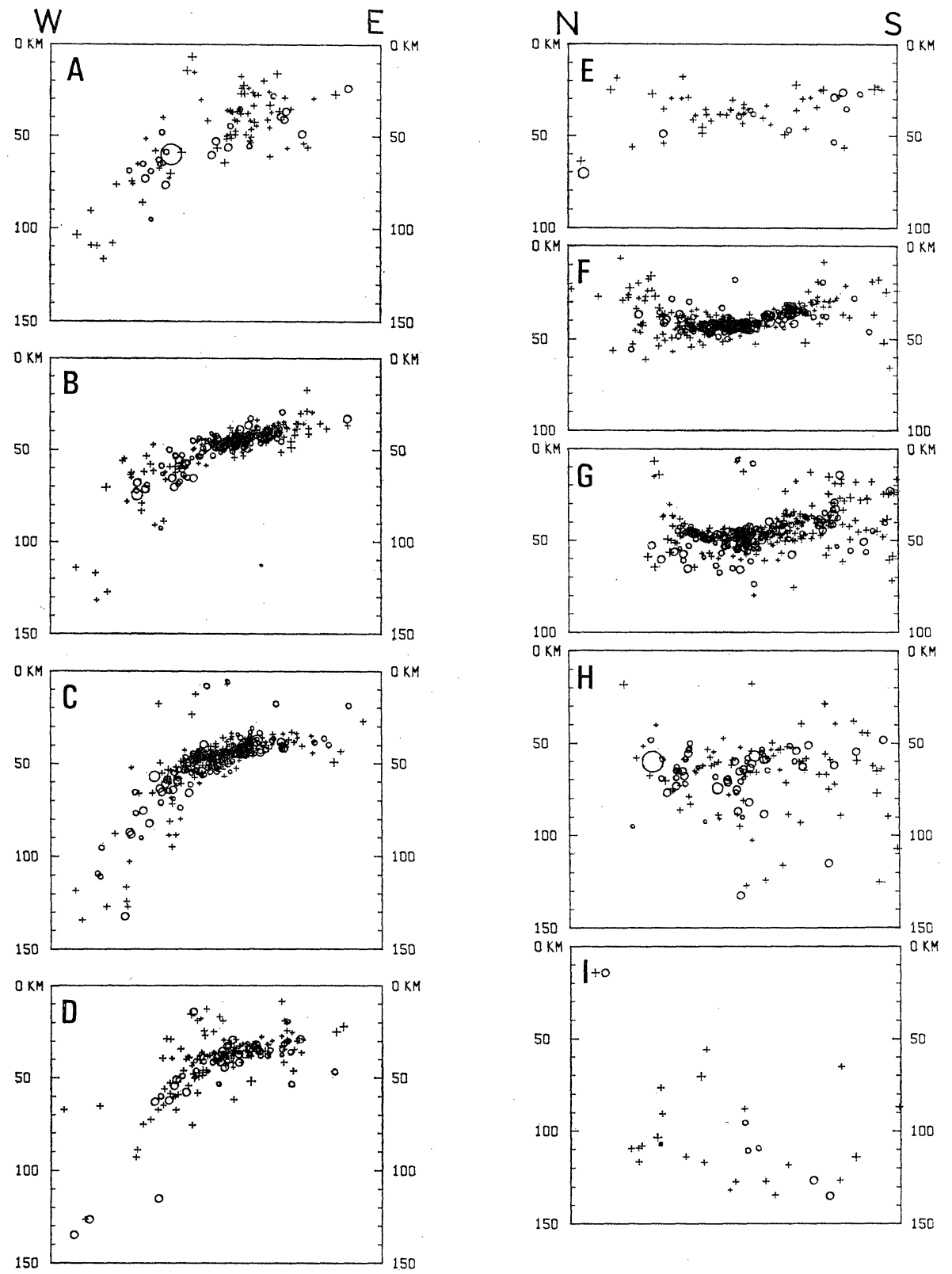

150

Fig. 17 (b). Vertical distributions of earthquakes fallen in each divided sections from A through I in Fig. 17 (a).

$\pm 5 \mathrm{~km}$ の範囲を考えると大部分の震源がその範囲内に含まれるが，その傾向は特に観測網に 近い地域で顕著である. 地震の発生する北限の位置に関しては不明確な点が多いが，比較的な めらかにかつ連続的に画いたものである。 
観測網周辺で地殼内の地震活動が非 常に低いことはこれまでに示した図に より明確であるが，その分布の特徴を 見るために上部地殼（深さ $20 \mathrm{~km}$ ま で）に発生した地震だけの震央分布を Fig. 19 に示す．前節で示したように 観測網から離れた地域の地震について は決定精度に問題があるので，観測網 に比較的近い範囲だけに注目する。図 では重なつていてわからないが，佐田 岬半島の 北岸付近のほぼ同じ場所で $M 1.0$ 程度の地震が深さ $5 \mathrm{~km} \sim 7 \mathrm{~km}$ の範囲に3 個発生している，それらを 含めて震源決定された数少ない地震の 大部分が佐田岬半島叔よびその走向沿 いに分布している傾向が見られる.

\section{§ 6. 議論}

以上に示してきたように，伊方観測 網による 4 年 3 ケ月間のデータの解析 から，観測網周辺の伊予灘捻よび豊後 水道付近の地震活動の特徵がかなり明 確にされてきた。そ主要な結果は次 の 5 点にまとめられる.

（1）最上部マントルの地震活動が 活発であるのに対し，地殼内の地震活 動は極めて低い。

（2）最上部マントルの地震は厚さ

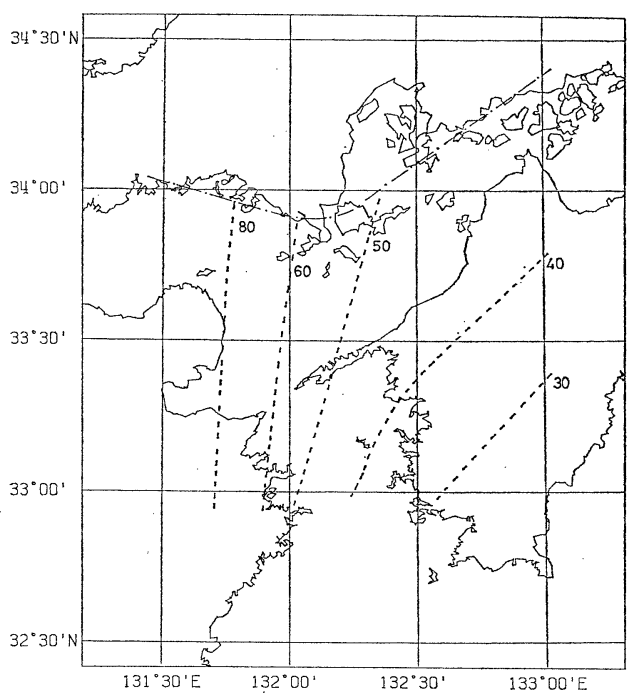

Fig. 18. Contour lines of average focal depths of hypocenters in the uppermost mantle (--) and the northern boundary of the seismic active zone in the uppermost mantle (-.-.-).

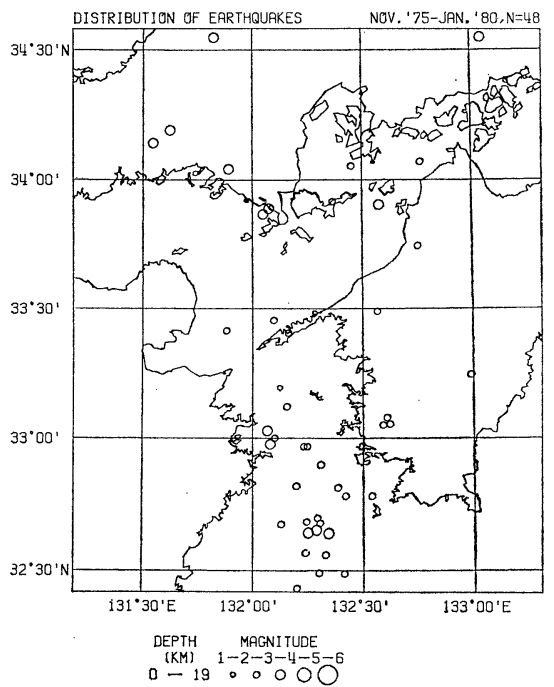

Fig. 19. Epicentral distribution of earthquakes selected from Fig. 16 by depth shallower than $20 \mathrm{~km}$.

$10 \mathrm{~km}$ 程度の非常に薄い層の中で発生して和り，その層は深さ $30 \sim 50 \mathrm{~km}$ の範囲では北西方 向に緩やかに傾斜し，深さ $50 \mathrm{~km}$ 以深では西方向に急傾斜している.

（3）最上部マントルの地震の発生する北限が比較的明膫に存在する. 
（4）伊方観測網に比較的近い範囲では, 上部地殼に発生する数少ない微小地震の大部分が 佐田岬半島およびその走向沿いに分布する.

（5）最上部マントルの地震活動を主体とするこの地域の地震活動の水準をマグニチュード と累積頻度の関係から見ると, 伊方観測網によるデータの示す水準は 1961 年以降の気象庁の データが示す水準や 16 世紀末以降の被害地震のデータが示す水準と整合している.

ここではこれらの結果に関連した問題について議論する.

最初に，最上部マントルの地震の分布と「フィリピン海プレート」の沈み込みとの関係につ いて考える. 南海トラフ沿いの巨大地震の発生から, 南海トラフに沿つて「フィリピン海プレ 一ト」が西南日本外帯下へ沈み込んでいると考えられているが，沈み込んでいる「プレート」 と地震活動の関連については未解明な点が少なくない. 基本的な問題として, 最上部マントル の地震が沈み込んでいる「プレート」の中で発生しているのか, それともそれに接触する「大 陸プレート」の内部で発生しているのかが議論されている [塩野 (1976); SHIONO (1977)].

九州の下では $100 \mathrm{~km}$ 以深で地震が発生しており, それらの地震は沈み込んだ「プレート」 の内部で発生していると考兄られている [SHIONO(1977).など]. しかし SHIONO (1974)によ れば, 1968 年豊後水道地震とその余震は「大陸プレート」内部で発生したと考えた方がそれ らの走時データを説明するのに都合がよいとされている．とこで 1968 年豊後水道地震と本稿 で決定した震源分布の関係を調べるために，SHIONO and MIKUMO (1975) によるこの地震の 断層面の傾斜方向 $\left(\mathrm{N} 67^{\circ} \mathrm{W}\right)$ に断層面と同じ巾 $(20 \mathrm{~km})$ の範囲をとり，伊方観測網により 決定された震源に対する断面図を作成し，その上に SHIONO and MIKUMO (1975) による断 層面と主震の位置を示したのが Fig. 20 である. この図から明らかなように, 1968 年豊後水

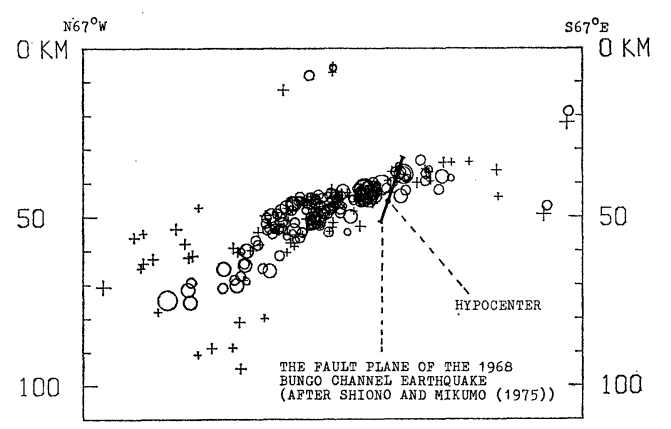

Fig. 20. Relation between the distribution of hypocenters in vertical section for the earthquakes whose hypocenters are determined in this study and the position of the fault plane of the 1968 Bungo channel earthquake of magnitude 6.6 by SHiono and Mikumo (1975).
道地震の断層面は地震が発生している 厚さ $10 \mathrm{~km}$ 程度の層をちようど切る 形になつており, 主震の位置はその層 のほぼ下面に相当している.このこと は SHIONO (1974) の結果が正しいと すれば，少なくもこの地域の深さ 30 $\sim 60 \mathrm{~km}$ の地震のほとんどが「大陸プ レート」内部で発生していることを意 味する。

しかし，本稿で明らかにした次のよ らな震源分布の特徵から見て, この地 
域の最上部マントルの地震は沈み込む「フィリピン海プレート」の内部で発生していると考兄 るのが自然であろう.まず, Fig. 18 の等深線で特徵的な点は $50 \mathrm{~km}$ 以深の等深線の走向が ほぼ南北であることであり, 九州南部から続く等深線があまり走向を変えずに地震の発生する 北限までのびていることを示している. この等深線の滑らかな走向の変化はこの地域の $50 \mathrm{~km}$ 以深の地震が九州南部や琉球弧と同様に「フィリピン海プレート」の内部で発生していること を示唆するものと考兄らる。 そして，Fig. 17 (b) の断面図にみられる分布の連続性から考 えて, 深さ $30 \sim 50 \mathrm{~km}$ の地震も「フィリピン海プレート」の内部で発生している可能性が大 きいであろう。また，Fig. 17 (b) の断面図に和いて地震が発生する層の上面が非常に明瞭で あることもとれらの地震が「フィリピン海プレート」の内部で発生していることを示唆すると 考えられる.

もし，この地域の最上部マントルの地震が「フィリピン海プレート」の内部で発生したとす ると, Fig. 18 に示した震源の等深線は沈み込む「プレート」の形をほぼ示すものと考えられ る. そして Fig. 20 に示した 1968 年豊後水道地震のような正断層型の地震も「プレート」の 変形に伴う地震として解釈できると考えられる. なお, この地域の地震の発震機構の特徵につ いては引き続く論文の中で詳しく検討する予定である.

次に, 佐田岬半島の北側を通つていると考兄られている中央構造線の地震学的位置付けに関 して考光る. 緒方 (1975) による佐田岬半島北岸海域の音波探査の結果によると, 結晶片岩と 和泉層群の境界として定義されている四国西部の中央構造線（狭義の中央構造線）は海域では 双海町下浜沖まで確認されるが，下浜以西では和泉層群は識別できず結晶片岩は更新世中期に 堆積した未固結〜半固結の泥質・砂質・砅質の地層と接してお り, その状態は九州まで続いて いる. そして, 海域に拈ける結晶片岩と和泉層群の境界拈よび結晶片岩と更新世中期に堆積し た層の境界は少なくとも未固結〜半固結の海底堆積物の層が堆積した以後は活動していないと 考学られており，佐田岬半島北岸海域の上記中央構造線は活断層でないと考兄られている。一 方, 岡田 (1972) は地質境界としての狭義の中央構造線とは別に, 和泉層群を切つている伊予 断層に活動的な広義の中央構造線の活動が受け継がれていると考えている.しかし，この伊予 断層も緒方 (1975) によると海中に没してから狭義の中央構造線に近接する手前で断層の最近 地質時代の活動性が消隇している.

以上のよらに四国西部から九州へかけては中央構造線は活動的でないと考光られる. 従つ て, 本稿で示した伊予灘和よび 豊後水道付近の地款内の 地震活動の非常な低さ一一岡野・他 (1978)の結果とあわせて見ると四国西部からこの地域にかけて共通の特徵と考えられる一一を， 四国中・東部の 中央構造線に 関し想定されているよらな将来の大地震の空白域（SHIMAZAKI 
(1976) はその領域に 1891 年濃尾地震以上のエネルギーが蓄積していると推定している) と同 様に考光ることは出来ないであろう，その点では松田（1975）が四国西部から九州にかけての 中央構造線に関して行なつている議論は，この地域の中央構造線の活動度を四国中・東部々同 様に考えている点に执いて，そして震央分布をもとにしてこの地域の被害地震を中央構造線の 活動と直接的に関連づけている点に括いて実証的でないと考兄られる．後者の点については， 本稿の震源分布の特徵からも推定され，かつ SHIONO (1980) も指摘するように，この地域の 過去の主要な被害地震を最上部マントルの地震であつたと推定する方が合理的と考えられるか らである.

\section{§7. おわりに}

本稿では四国電力 (株)により観測されている微小地震観測網のデータを解析し，伊予灘拉よ び豊後水道付近の震源分布の詳細な特徵を明らかにした。特に最上部マントルの地震について は，厚さ $10 \mathrm{~km}$ 程度の非常に薄い層の中に分布していることを示し，平均的な震源の等深線 の形を明らかにした．この等深線の形はこの地域の下に沈み込んでいる「フィリピン海プレー ト」の形を示すものと考えられる. 引き続く論文ではこの地域の地震の発震機構の性質を調べ, 等深線の形——「ィリピン海プレート」の形——との関連を検討する予定である.

\section{謝 辞}

解析の機会を与兄ていただいた四国電力（株）関係各位に感謝します．解析全般について御 助言を得た九州産業大学表俊一郎教授, 京都大学防㷋研究所岸本兆方教授括よび尾池和夫助教 授，また結果について議論していただいた高知大学理学部岡野健之助教授の各位に深く感謝し ます。

計算，作図は日本エヌ・ユー・エス（株）のミニコンピュータTI-FS 990/10 により行なつ た。また，当社の河合和子寨には記録の再生，読み取り，データ整理，作図を手伝つていただ いた。記して感謝の意を表します。

\section{文献}

青木治三・村松郁栄, 1974 , 御衣母一外山測線に沿亏近畿・四国地方の地殼構造, 地震 2, 27, 104-109. 松田時彦, 1975, 活断層から発生する地震の規模と周期について, 地震 2, 28, 269-283.

溝上 恵, 1976, 地殼底地震活動の特性, 地震予知研究シンポジウム (1976), 97-103.

緒方正虔, 1975 , 佐田岬半島北岸海域の地質構造一音波探査による海底地質の考察一, 電力中央研究 所報告, 研究報告: 375006 .

尾池和夫, 1975 , 鳥取微小地震観測所の震源表について, 地震 $2,28,331-346$.

岡田篤正，1972，四国北西部に批る 中央構造線の第四紀断層運動，愛知県立大学文学部論集，23, 
$68-94$.

岡野健之助・木村昌三・許斐 正，1978，四国中・東部に拈恬る地震活動，地震 2, 31，63-72.

ShImazaki, K., 1976, Intra-Plate Seismicity Gap along the Median Tectonic Line and Oblique Plate Convergence in Southwest Japan, Tectonophys., 31, 139-156.

Shrono, K., 1974, Travel Time Analysis of Relatively Deep Earthquakes in Southwest Japan with Special Reference to the Underthrusting of the Philippine Sea Plate, J. Geosci., Osaka City Univ., 18, 37-59.

塩野清治, 1976, 西南日本に佂ける発震機構とその地学的意味, 地質学論集, 12, 99-108.

ShIoNo, K., 1977, Focal Mechanism of Major Earthquakes in Southwest Japan and Their Tectonic Significance, J. Phys. Earth, 25, 1-26.

Shrono, K., 1980, Seismological Study on the Median Tectonic Line of Southwest Japan, Memoirs Geol. Soc. Japan, No. 18, 155-174.

ShIoNo, K. and M. MASAOKA, 1978, Temporal Seismological Observation on the Sada-misaki Peninsula, Japan-Subcrustal Earthquakes in Iyonada and Bungo Channel, J. Geosci., Osaka City Univ., 21, 17-26.

Shiono, K. and T. Mikumo, 1975, Tectonic Implications of Subcrustal Normal Faulting Earthquakes in the Western Shikoku Region, J. Phys. Earth, 32, 257-278.

津村建四郎，1967，振動継続時間による地震のマグニチュードの決定，地震 2, 20, 30-40.

宇佐美竜夫, 1975 , 資料日本被害地震総覧, 東京大学出版会.

宇津徳治, 1965 , 地震の規模別度数の統計式 $\log n=a-b M$ の係数 $b$ を求める一方法, 北海道大学地 球物理報告, 13, 99-104.

宇津徳治, 1979,1885 年 1925 年の日本の地震活動- $M 6$ 以上の地震及び被害地震の再調査一, 地 震研究所巣報, 54, 253-308. 